\title{
Investigation of the Relationship Between Individuals' Knowledge Levels Regarding Coronavirus Disease and E-Health Literacy Levels
}

\author{
Metin YILDIZ1 ${ }^{10}$, Mehmet Salih YILDIRIM² ${ }^{\text {(D) }}$, Guray OKYAR ${ }^{1}$ (D) \\ ${ }^{1}$ Department of Nursing, Agri Ibrahim Cecen University School of Health, Agri, Turkey \\ ${ }^{2}$ Vocational School of Health Services, Agri Ibrahim Cecen University School of Health, Agri, Turkey
}

\begin{abstract}
Background This research investigated the relationship between individuals' knowledge levels regarding coronavirus disease and e-health literacy levels.

Material and Methods This study was designed as a descriptive type, was carried out between June and July 2020 by individuals living in the eastern provinces of Turkey.

Results According to the findings obtained from the study, it was found that the total mean score of individuals for Knowledge Test for Coronavirus Disease was 13.59 22.30. E-Health Literacy Level total score mean was found to be $26.12 \pm 9.35$. It was found that there was a positive statistically significant relationship between the level of knowledge regarding coronavirus disease and the total score means of e-health literacy $(\mathrm{p}<0.05)$.

Conclusions It was determined that the mean level of the knowledge level of the individuals for coronavirus disease was high, and the e-health literacy level was mean. It is recommended that the study be carried out in larger groups.
\end{abstract}

Turk J Int Med 2021;3(1): 13-20

DOI: $10.46310 /$ tjim.800533

Keywords: e-health literacy, coronavirus disease, individuals 


\section{Introduction}

COVID-19, which was detected in Wuhan city of Hubei province of China at the end of 2019 and spread to the whole world in a short time, has become a very important and urgent public health problem. The existing treatment of patients for the disease and efforts to prevent the spread of the virus while new information is obtained, on the other hand, scientific studies are conducted, approaches are frequently updated. There is no vaccine yet developed against the virus. The most important way to prevent disease is not to be exposed to the virus. ${ }^{1}$ According to the available evidence, the SARS-CoV-2 virus is transmitted through human droplets and contact. Effective methods of contamination are the washing of hands frequently with soap and water for at least 20 seconds. $^{2}$ Hand washing is very effective in killing viruses likely to be present. ${ }^{3}$ Washing hands is very important, especially when found in public places or when contacting other people. In cases where water and soap cannot be reached, it is recommended to use hand disinfectants containing at least $60 \%$ alcohol. ${ }^{1,4}$ In addition to hand hygiene, it should be paid attention that the hands do not come into contact with the face, eyes and mouth during the day. ${ }^{3}$ One of the most important protection methods is to maintain social distance. ${ }^{5}$ The virus can spread to a distance of 1-2 meters by droplet. It is important to make this distance a habit in daily life and to avoid close contacts in the society. ${ }^{1}$ Avoid crowded areas as much as possible and should not travel unless necessary. ${ }^{6}$ Another effective measure is the regular cleaning and disinfection of frequently contacted surfaces. Environmental cleanliness should be given importance, transportation means should be frequently ventilated and common surfaces should be disinfected. ${ }^{7}$ It is effective and evidence-based measures to suspend mass meetings and activities, which are recommended for social isolation and implemented in our country, by taking into account the possibility of infecting children in adults even though the effects of the disease in children are poor. ${ }^{8} 41.5 \%$ of individuals think that the internet is a good source of information about health. ${ }^{9}$ In the present day, the internet is used frequently, and it is stated that their perceptions and attitudes about e-health literacy are little known, and that they need to browse the internet securely, especially for important health issues. ${ }^{10,11}$ The effectiveness of measures for coronavirus disease depends on the level of knowledge of the community. This research investigated the relationship between individuals' knowledge levels regarding coronavirus disease and e-health literacy levels.

\section{Material and Methods}

Descriptive research type planned this study was conducted between June and July 2020 by individuals living in the eastern provinces of Turkey.

The universe of the research; It has created an individual living in the eastern provinces of Turkey. The inclusion of a sample of the research work of individuals living in the eastern provinces of Turkey has created accepting individuals.

\section{Collection of Data}

In the collection of research data, Introductory Information Form, Knowledge Test for Coronavirus Disease and E-Health Literacy Scale. After explaining the purpose of the research, after obtaining verbal consent from those who voluntarily agreed to participate in the research, the data were collected online with the Google form prepared by the researchers.

\section{Data Collection Tools}

Introductory Information Form: It consists of questions that are created by researchers and contain the introductory features of individuals.

Knowledge Test for Coronavirus Disease: This test is created with questions that will measure the level of knowledge and cover the whole subject. A minimum of 0 and a maximum of 20 points can be obtained from the scale consisting of 20 questions. True, false and I don't know options are found in the scale and 1 point is taken from the true option and 0 points are taken from the wrong and I don't know option. Questions 2, 4, 6, 14, 15 and 17 are inverted. The increase in the score indicates that the level of knowledge has increased. In our study, Cronbach Alpha value was found to be 0.72 .

E-Health Literacy Scale: "E-Health Literacy Scale" developed by Cameron D. Norman and Harvey A. Skinner in 2006 and accepted by performing validity and reliability tests was adapted to Turkish by Gencer. ${ }^{12}$ Since the method used in the e-Health literacy scale is a 
5-point Likert type measurement, reliability was calculated with the Cronbach Alpha method. The calculated value of 0.91 alpha has a high degree of reliability since it is between 0.80 and $1.00 .^{12} \mathrm{In}$ our study, Cronbach Alpha value was found to be 0.96 .

\section{Statistical Analysis}

The analysis of the data was done on the computer using the SPSS statistical software. Frequency, descriptives, percentage, mean, standard deviation, median, explore and normality plots with tests were used as descriptive statistical methods. Kolmogorov - Smirnov test was used to test normality distribution with analytical tests. Mann-Whitney U test was used for binary groups.
Kruskal-Wallis test was used for groups more than two. Spearman correlation test was used to determine whether there is a linear relationship between the two numerical measurements, the direction and severity of this relationship, if any. In our study $(\mathrm{p}<0.05)$, it was accepted as statistically significant difference.

\section{Ethical Principles}

This study was approved by the Agri Ibrahim Cecen University Scientific Research Ethics Committee with the protocol number of 95 was in accordance with the ethical standards established in the Declaration of Helsinki.

Table 1. Introductory characteristics of individuals $(\mathrm{N}=611)$

\begin{tabular}{|c|c|c|c|}
\hline \multicolumn{2}{|l|}{ Variables } & \multirow{2}{*}{$\begin{array}{l}\text { n } \\
476 \\
135\end{array}$} & \multirow{2}{*}{$\begin{array}{l}\% \\
77.9 \\
22.1\end{array}$} \\
\hline Nationality & $\begin{array}{l}\text { Turkey } \\
\text { Azerbaijan }\end{array}$ & & \\
\hline Gender & $\begin{array}{l}\text { Female } \\
\text { Male }\end{array}$ & $\begin{array}{l}362 \\
249\end{array}$ & $\begin{array}{l}59.2 \\
40.8\end{array}$ \\
\hline Marital status & $\begin{array}{l}\text { Single } \\
\text { Married }\end{array}$ & $\begin{array}{l}454 \\
157\end{array}$ & $\begin{array}{l}74.3 \\
25.7\end{array}$ \\
\hline Education Level & $\begin{array}{l}\text { Primary education } \\
\text { Secondary education } \\
\text { High education }\end{array}$ & $\begin{array}{l}33 \\
288 \\
290\end{array}$ & $\begin{array}{l}5.4 \\
47.1 \\
47.5\end{array}$ \\
\hline Income rate & $\begin{array}{l}\text { Less than income } \\
\text { Income equal to expense } \\
\text { More than income }\end{array}$ & $\begin{array}{l}267 \\
255 \\
89\end{array}$ & $\begin{array}{l}43.7 \\
41.7 \\
14.6\end{array}$ \\
\hline Health Insurance & $\begin{array}{l}\text { Yes } \\
\text { No }\end{array}$ & $\begin{array}{l}413 \\
198\end{array}$ & $\begin{array}{l}67.6 \\
32.4\end{array}$ \\
\hline Job & $\begin{array}{l}\text { Officer } \\
\text { Health personnel } \\
\text { Worker } \\
\text { Not working } \\
\text { Housewife } \\
\text { Other }\end{array}$ & $\begin{array}{l}61 \\
59 \\
39 \\
121 \\
28 \\
303\end{array}$ & $\begin{array}{l}10.0 \\
9.7 \\
6.4 \\
19.8 \\
4.6 \\
49.6\end{array}$ \\
\hline $\begin{array}{l}\text { Information channel for } \\
\text { coronavirus disease }\end{array}$ & $\begin{array}{l}\text { Television } \\
\text { Internet } \\
\text { Scientific works }\end{array}$ & $\begin{array}{l}206 \\
345 \\
60\end{array}$ & $\begin{array}{l}33.7 \\
56.5 \\
9.8\end{array}$ \\
\hline $\begin{array}{l}\text { The idea of taking } \\
\text { adequate precautions for } \\
\text { coronavirus disease }\end{array}$ & $\begin{array}{l}\text { Yes } \\
\text { No }\end{array}$ & $\begin{array}{l}385 \\
226\end{array}$ & $\begin{array}{l}63.0 \\
37.0\end{array}$ \\
\hline $\begin{array}{l}\text { Thought of losing } \\
\text { his/her job due to } \\
\text { coronavirus disease }\end{array}$ & $\begin{array}{l}\text { Yes } \\
\text { No }\end{array}$ & $\begin{array}{l}235 \\
376\end{array}$ & $\begin{array}{l}38.5 \\
61.5\end{array}$ \\
\hline $\begin{array}{l}\text { Have you applied } \\
\text { coronavirus disease to } \\
\text { it? }\end{array}$ & $\begin{array}{l}\text { Yes } \\
\text { No }\end{array}$ & $\begin{array}{l}83 \\
528\end{array}$ & $\begin{array}{l}13.6 \\
86.4\end{array}$ \\
\hline $\begin{array}{l}\text { How stressful do you } \\
\text { feel due to coronavirus } \\
\text { disease }\end{array}$ & $\begin{array}{l}\text { Low } \\
\text { Middle } \\
\text { High }\end{array}$ & $\begin{array}{l}95 \\
319 \\
197\end{array}$ & $\begin{array}{l}15.5 \\
52.2 \\
32.2\end{array}$ \\
\hline & & $\bar{X} \pm$ & \\
\hline Age & & $\begin{array}{r}25.13 \pm \\
(\min .18, \mathrm{n}\end{array}$ & \\
\hline
\end{tabular}




\section{Results}

Turkey citizens of $77.9 \%$ of the individuals participating in the study, of $59.2 \%$ were female, were single of $74.3 \%$, higher education graduates, $47.5 \%$, is less than costs of revenues of $43.7 \%$, that of the $67.6 \%$ health insurance, $49.6 \%$. The other group has profession, $56.5 \%$ of them get information from the internet, $63.0 \%$ of them think that they take enough precautions, $61.5 \%$ of them think they will not lose their job due to the corona, $86.4 \%$ of them do not apply online corona, $52.2 \%$ of them have coronavirus disease. It was determined that she experienced moderate stress due to her and the mean age of the group was $25.13 \pm 7.41$ (Table 1).
The Knowledge Test for Coronavirus Disease was found to be statistically significantly higher in higher education graduates, those with health insurance, those working as health personnel, those who read scientific studies as a corona information channel, and those who did not have the idea of losing their job due to corona $(\mathrm{p}<0.05)$ (Table 2).

E-Health literacy Level score was found to be statistically significantly higher in women, higher education graduates, those with health insurance, those working as health personnel, those who read scientific studies as a corona information channel, and those who did not have the idea of losing their job due to corona $(\mathrm{p}<0.05)$ (Table 3$)$.

Table 2. Comparison of individuals' demographic characteristics and knowledge test for coronavirus disease

\begin{tabular}{|c|c|c|c|c|}
\hline Variables & & $\mathbf{n}$ & $\bar{X} \pm \mathbf{S D}$ & Statistic \\
\hline Nationality & $\begin{array}{l}\text { Turkey } \\
\text { Azerbaijan }\end{array}$ & $\begin{array}{l}476 \\
135\end{array}$ & $\begin{array}{l}13.66 \pm 2.24 \\
13.37 \pm 2.52\end{array}$ & $\begin{array}{l}U=30651.50 \\
p=0.410\end{array}$ \\
\hline Gender & $\begin{array}{l}\text { Female } \\
\text { Male }\end{array}$ & $\begin{array}{l}362 \\
249\end{array}$ & $\begin{array}{l}13.63 \pm 2.29 \\
13.54 \pm 2.32\end{array}$ & $\begin{array}{l}U=43801.50 \\
p=0.551\end{array}$ \\
\hline Marital status & $\begin{array}{l}\text { Single } \\
\text { Married }\end{array}$ & $\begin{array}{l}454 \\
157\end{array}$ & $\begin{array}{l}13.59 \pm 2.22 \\
13.59 \pm 2.54\end{array}$ & $\begin{array}{l}\mathrm{U}=35237.00 \\
\mathrm{P}=0.832\end{array}$ \\
\hline Education Level & $\begin{array}{l}\text { Primary } \\
\text { Secondary } \\
\text { High education }\end{array}$ & $\begin{array}{l}33 \\
288 \\
290\end{array}$ & $\begin{array}{l}12.33 \pm 2.80 \\
13.44 \pm 2.19 \\
13.89 \pm 2.30\end{array}$ & $\begin{array}{l}\mathrm{KW}=12.061 \\
\mathrm{p}=0.002\end{array}$ \\
\hline Income rate & $\begin{array}{l}\text { Less than income } \\
\text { Income equal to expense } \\
\text { More than income }\end{array}$ & $\begin{array}{l}267 \\
255 \\
89\end{array}$ & $\begin{array}{l}13.47 \pm 2.18 \\
13.54 \pm 2.28 \\
14.12 \pm 2.67\end{array}$ & $\begin{array}{l}\mathrm{KW}=3.448 \\
\mathrm{p}=0.178\end{array}$ \\
\hline Health Insurance & $\begin{array}{l}\text { Yes } \\
\text { No }\end{array}$ & $\begin{array}{l}413 \\
198\end{array}$ & $\begin{array}{l}13.88 \pm 2.26 \\
12.99 \pm 2.29\end{array}$ & $\begin{array}{l}U=35386.00 \\
p=0.000\end{array}$ \\
\hline Job & $\begin{array}{l}\text { Officer } \\
\text { Health personnel } \\
\text { Worker } \\
\text { Not working } \\
\text { Housewife } \\
\text { Other }\end{array}$ & $\begin{array}{l}61 \\
59 \\
39 \\
121 \\
28 \\
303\end{array}$ & $\begin{array}{l}14.08 \pm 2.49 \\
14.38 \pm 2.55 \\
12.02 \pm 2.18 \\
13.47 \pm 2.10 \\
13.10 \pm 2.04 \\
13.64 \pm 2.23\end{array}$ & $\begin{array}{l}\mathrm{KW}=28.200 \\
\mathrm{p}=\mathbf{0 . 0 0 0}\end{array}$ \\
\hline $\begin{array}{l}\text { Information channel } \\
\text { for coronavirus } \\
\text { disease }\end{array}$ & $\begin{array}{l}\text { Television } \\
\text { Internet } \\
\text { Scientific works }\end{array}$ & $\begin{array}{l}206 \\
345 \\
60\end{array}$ & $\begin{array}{l}13.38 \pm 2.19 \\
13.56 \pm 2.22 \\
14.53 \pm 2.87\end{array}$ & $\begin{array}{l}K W=9.902 \\
p=0.007\end{array}$ \\
\hline $\begin{array}{l}\text { The idea of taking } \\
\text { adequate precautions } \\
\text { for coronavirus } \\
\text { disease }\end{array}$ & $\begin{array}{l}\text { Yes } \\
\text { No }\end{array}$ & $\begin{array}{l}385 \\
226\end{array}$ & $\begin{array}{l}13.64 \pm 2.24 \\
13.51 \pm 2.41\end{array}$ & $\begin{array}{l}\mathrm{U}=42152.00 \\
\mathrm{p}=0.517\end{array}$ \\
\hline $\begin{array}{l}\text { Thought of losing } \\
\text { his/her job due to } \\
\text { coronavirus disease }\end{array}$ & $\begin{array}{l}\text { Yes } \\
\text { No }\end{array}$ & $\begin{array}{l}235 \\
376\end{array}$ & $\begin{array}{l}12.94 \pm 2.25 \\
14.01 \pm 2.24\end{array}$ & $\begin{array}{l}U=32977.00 \\
p=0.000\end{array}$ \\
\hline $\begin{array}{l}\text { Have you applied } \\
\text { coronavirus disease } \\
\text { to it? }\end{array}$ & $\begin{array}{l}\text { Yes } \\
\text { No }\end{array}$ & $\begin{array}{l}83 \\
528\end{array}$ & $\begin{array}{l}13.72 \pm 2.39 \\
13.57 \pm 2.29\end{array}$ & $\begin{array}{l}U=21032.50 \\
p=0.553\end{array}$ \\
\hline $\begin{array}{l}\text { How stressful do you } \\
\text { feel due to } \\
\text { coronavirus disease }\end{array}$ & $\begin{array}{l}\text { Low } \\
\text { Middle } \\
\text { High }\end{array}$ & $\begin{array}{l}95 \\
319 \\
197\end{array}$ & $\begin{array}{l}13.49 \pm 2.31 \\
13.66 \pm 2.35 \\
13.53 \pm 2.23\end{array}$ & $\begin{array}{l}\mathrm{KW}=0.954 \\
\mathrm{p}=0.621\end{array}$ \\
\hline
\end{tabular}


According to the findings obtained from the study, it was found that the lowest mean score was 6 and the highest score was 20 and the mean score was $13.59 \pm 2.30$. It was determined that the mean score level of the individuals for coronavirus disease was high. E-Health literacy Level total score mean was $26.12 \pm 9.35$ and the lowest score was 8 and the highest score was 40 . E-Health literacy Level mean score was determined to be high (Table 4).

It was found that there was a statistically significant correlation between the level of knowledge and e-health literacy level for coronavirus disease $(\mathrm{p}<0.05)$ (Table 5).

\section{Discussion}

It is very important to stay away from false information in preventing disease and combating the epidemic. Speculative suggestions made because of incomplete information and evidencebased approaches or to benefit from panic environment are far from scientific and such explanations cause more harm than benefit in society.

According to the findings obtained from the study, it was found that the lowest mean score was 6 and the highest score was 20 and the mean score was $13.59 \pm 2.30$. It was determined that the mean score level of the individuals for coronavirus disease was high. Case of Turkey

Table 3. Comparison of individuals' demographic characteristics and e-Health literacy level scores

\begin{tabular}{|c|c|c|c|c|}
\hline Variables & & $\mathbf{n}$ & $\bar{X} \pm$ SD & Statistic \\
\hline Nationality & $\begin{array}{l}\text { Turkey } \\
\text { Azerbaijan }\end{array}$ & $\begin{array}{l}476 \\
135\end{array}$ & $\begin{array}{l}25.91 \pm 9.30 \\
26.87 \pm 9.54\end{array}$ & $\begin{array}{l}U=29889.50 \\
p=0.215\end{array}$ \\
\hline Gender & $\begin{array}{l}\text { Female } \\
\text { Male }\end{array}$ & $\begin{array}{l}362 \\
249\end{array}$ & $\begin{array}{l}26.80 \pm 9.02 \\
25.14 \pm 9.75\end{array}$ & $\begin{array}{l}U=40873.00 \\
p=0.050\end{array}$ \\
\hline Marital status & $\begin{array}{l}\text { Single } \\
\text { Married }\end{array}$ & $\begin{array}{l}454 \\
157\end{array}$ & $\begin{array}{l}26.25 \pm 9.36 \\
25.75 \pm 9.34\end{array}$ & $\begin{array}{l}U=34718.00 \\
p=0.628\end{array}$ \\
\hline Education Level & $\begin{array}{l}\text { Primary } \\
\text { Secondary } \\
\text { High education }\end{array}$ & $\begin{array}{l}33 \\
288 \\
290\end{array}$ & $\begin{array}{l}24.30 \pm 6.51 \\
25.42 \pm 9.43 \\
27.02 \pm 9.49\end{array}$ & $\begin{array}{l}\mathrm{KW}=9.016 \\
\mathrm{p}=0.011\end{array}$ \\
\hline Income rate & $\begin{array}{l}\text { Less than income } \\
\text { Income equal to expense } \\
\text { More than income }\end{array}$ & $\begin{array}{l}267 \\
255 \\
89\end{array}$ & $\begin{array}{l}24.81 \pm 9.55 \\
26.80 \pm 8.96 \\
28.10 \pm 9.41\end{array}$ & $\begin{array}{l}\mathrm{KW}=3.448 \\
\mathrm{p}=0.178\end{array}$ \\
\hline Health Insurance & $\begin{array}{l}\text { Yes } \\
\text { No }\end{array}$ & $\begin{array}{l}413 \\
198\end{array}$ & $\begin{array}{l}27.04 \pm 9.19 \\
24.21 \pm 9.43\end{array}$ & $\begin{array}{l}U=33162.50 \\
p=0.000\end{array}$ \\
\hline Job & $\begin{array}{l}\text { Officer } \\
\text { Health personnel } \\
\text { Worker } \\
\text { Not working } \\
\text { Housewife } \\
\text { Other }\end{array}$ & $\begin{array}{l}61 \\
59 \\
39 \\
121 \\
28 \\
303\end{array}$ & $\begin{array}{l}28.03 \pm 8.89 \\
28.94 \pm 8.62 \\
20.17 \pm 9.94 \\
25.67 \pm 9.61 \\
21.71 \pm 9.45 \\
26.54 \pm 8.98\end{array}$ & $\begin{array}{l}\mathrm{KW}=28.200 \\
\mathrm{p}=0.000\end{array}$ \\
\hline $\begin{array}{l}\text { Information channel for } \\
\text { coronavirus disease }\end{array}$ & $\begin{array}{l}\text { Television } \\
\text { Internet } \\
\text { Scientific works }\end{array}$ & $\begin{array}{l}206 \\
345 \\
60\end{array}$ & $\begin{array}{l}24.57 \pm 9.14 \\
26.23 \pm 9.40 \\
30.78 \pm 8.27\end{array}$ & $\begin{array}{l}\mathrm{KW}=9.902 \\
\mathrm{p}=0.007\end{array}$ \\
\hline $\begin{array}{l}\text { The idea of taking } \\
\text { adequate precautions for } \\
\text { coronavirus disease }\end{array}$ & $\begin{array}{l}\text { Yes } \\
\text { No }\end{array}$ & $\begin{array}{l}385 \\
226\end{array}$ & $\begin{array}{l}26.74 \pm 8.95 \\
25.06 \pm 9.93\end{array}$ & $\begin{array}{l}U=39078.50 \\
p=0.035\end{array}$ \\
\hline $\begin{array}{l}\text { Thought of losing } \\
\text { his/her job due to } \\
\text { coronavirus disease }\end{array}$ & $\begin{array}{l}\text { Yes } \\
\text { No }\end{array}$ & $\begin{array}{l}235 \\
376\end{array}$ & $\begin{array}{l}23.89 \pm 9.38 \\
27.51 \pm 9.07\end{array}$ & $\begin{array}{l}U=33700.50 \\
p=0.000\end{array}$ \\
\hline $\begin{array}{l}\text { Have you applied } \\
\text { coronavirus disease to } \\
\text { it? }\end{array}$ & $\begin{array}{l}\text { Yes } \\
\text { No }\end{array}$ & $\begin{array}{l}83 \\
528\end{array}$ & $\begin{array}{l}27.15 \pm 9.52 \\
25.96 \pm 9.32\end{array}$ & $\begin{array}{l}U=20304.00 \\
p=0.281\end{array}$ \\
\hline $\begin{array}{l}\text { How stressful do you } \\
\text { feel due to coronavirus } \\
\text { disease }\end{array}$ & $\begin{array}{l}\text { Low } \\
\text { Middle } \\
\text { High }\end{array}$ & $\begin{array}{l}95 \\
319 \\
197\end{array}$ & $\begin{array}{l}27.43 \pm 9.99 \\
26.73 \pm 8.75 \\
24.49 \pm 9.80\end{array}$ & $\begin{array}{l}\mathrm{KW}=0.954 \\
\mathrm{p}=0.621\end{array}$ \\
\hline
\end{tabular}


Table 4. Knowledge test for coronavirus disease and e-Health literacy level total score means

\begin{tabular}{lll}
\hline & $\bar{X} \pm$ SD & Min- Max \\
Knowledge Test for Coronavirus Disease & $13.59 \pm 2.30$ & $6.00-20.00$ \\
E-Health Literacy Level & $26.12 \pm 9.35$ & $8.00-40.00$
\end{tabular}

and should be seen in many countries before the relevant ministries and local governments, as well as greater use of the media in the very origin is thought to have become more conscious society.

In our study, the mean knowledge level for coronavirus disease was found statistically significantly higher in higher education graduates $(p<0.05)$. In the study conducted by Demirbilek on the knowledge, attitude and behavior of nurses about flu vaccine, it was found that those with higher education level had higher knowledge level. ${ }^{13}$ In the study carried out by Tekbas towards infectious diseases, it was found that individuals with low education level had a low mean score. ${ }^{14}$

In our study, the mean knowledge level for coronavirus disease was found statistically significantly higher in those with health insurance $(p<0.05)$. It is thought that there is no similar study in the literature and this is due to the insufficiency of access to resources depending on the income level of those who do not have health insurance.

In our study, the mean knowledge level for coronavirus disease was found to be statistically significantly higher in those working as health personnel $(p<0.05)$. The fact that healthcare personnel receive information face-to-face and on the web in continuous preventive and therapeutic areas also suggests that the level of knowledge is high when they learn by experience rather than just knowledge.

In our study, the mean knowledge level for coronavirus disease was found to be statistically significantly higher in those who read scientific studies as a channel of receiving information for coronavirus disease $(p<0.05)$. In addition to the information that needs to be produced based on evidence in the light of the information that is renewed every day, some wrong or useless applications can cause disinformation either in media tools such as television, newspapers or via social media. In this context, in order to reach correct information, it is considered that scientific evidence should be avoided, the source of the transferred information should be checked and filtered.

In our study, the mean knowledge level for coronavirus disease was found to be statistically significantly higher in those who did not have the idea of losing their job due to coronavirus disease $(p<0.05)$. It is thought that the individuals who have a specific job and who are deemed authorized by their institutions are isolated from home and that the period of benefiting from social media, television and scientific studies for the purpose of occupation is high. E-Health Literacy Level was found to be $26.12 \pm 9.35$ on mean. Similar results were found in the literature. ${ }^{15-17}$

E-Health literacy Level mean score was found statistically significantly higher in women $(p<0.05)$. Ertas et al. similar results were found in the study conducted by. ${ }^{18}$

E-Health Literacy Level mean score was found statistically significantly higher in higher education graduates $(p<0.05)$. Similar results were found in the literature..$^{18-20}$

E-Health Literacy Level score mean was found to be statistically significantly higher in those with health insurance $(p<0.05)$. This situation suggests that it is due to the limited access to the internet and social media due to the financial situation. In the studies in the literature, it was found that as the level of income increases, literacy scores also increase. $^{21,22}$

Table 5. Relationship Between Knowledge Test for Coronavirus Disease and E-Health Literacy Level Total Score Means

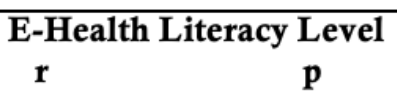

$\begin{array}{lll}\text { Knowledge Test for Coronavirus Disease } & 0.301 & 0.000\end{array}$ 
E-Health Literacy Level mean score was found to be statistically significantly higher in those working as health personnel $(p<0.05)$. In addition to a health education focused education, it is thought that the unit they work in is high due to the fact that the internet and health related concepts are widely included.

E-Health Literacy Level score mean was found to be statistically significantly higher in those who read scientific studies as a channel to receive information from coronavirus disease $(p<0.05)$. This situation makes us think that it is caused by the fact that there is a lot of wrong information besides useful information on the internet. Scientific studies based on evidence are thought to increase e-health literacy.

E-Health Literacy Level mean score was found statistically significantly higher in those who did not have the idea of losing their job due to coronavirus disease $(p<0.05)$. The idea of losing his job suggests that health literacy is lower due to the inadequate opportunities, since it is made up of individuals who are in the working class and who do not have a high income.

It was found that there was a positive statistically significant relationship between the level of knowledge regarding coronavirus disease and the total score means of e-health literacy $(p<0.05)$. This situation suggests that in parallel with the increase in interest in e-health literacy, the intake of information about coronavirus disease has also increased.

\section{Conclusions}

It was determined that the knowledge level of the individuals for coronavirus disease was high, and the e-health literacy level was mean. It is recommended that the study be carried out in larger groups.

\section{Conflict of interest}

The authors declared that there are no potential conflicts of interest with respect to the research, authorship, and/or publication of this article.

\section{References}

1. Centers for Disease Control and Prevention. Coronavirus Disease 2019 (COVID-19) How to protect yourself. Available at: https://www.cdc.gov/coronavirus/2019. ncov/prepare/prevention.html. Accessed June 06, 2020.

2. Halk Saglıg1 Genel Müdürlügü. COVID-19 (yeni koronavirüs hastalıgı'na yakalanmamak için öneriler. Available at: https://hsgm.saglik.gov.tr/tr/covid-19-yenikoronavirushastaligi-na-yakalanmamak-icin-oneriler. html. Accessed June 06, 2020.

3. World Health Organization. Coronavirus disease (COVID-19) advice for the public. Available at: https://www.who.int/emergencies/diseases/novelcoronavirus-2019/advice-for-public. Accessed June 06, 2020.

4. CentersforDiseaseControlandPrevention. Environmental cleaning and disinfection recommendations. Available at: https://www.cdc.gov/coronavirus/2019ncov/ community/organizations/cleaningdisinfection.html. Accessed June 06, 2020.

5. World Health Organization. Rational use of personal protective equipment (PPE) for coronavirus disease (COVID-19). Available at: https://apps.who.int/ iris / bitstrea m/handle/10665/331498/W HO 2019nCoVIPCPPE_use2020.2-eng.pdf. Accessed June 06, 2020.

6. Patient education: Coronavirus disease 2019 (COVID-19) overview (The Basics). UpToDate 2020. Available at: https://www.uptodate.com/contents/coronavirusdisease-2019-covid-19-overview-the-basics. Accessed June 06, 2020.

7. Centers for Disease Control and Prevention. What every American and community can do now to decrease the spread of the coronavirus. Available at: https://www. cdc.gov/coronavirus/2019-ncov/downloads/workplaceschool-and-home-guidance.pdf. Accessed June 06, 2020.

8. European Centre for Disease Prevention and Control. Novel coronavirus disease 2019 (COVID-19) pandemic: increased transmission in the EU/EEA and the UK sixth update. March 12, 2020. Available at: https://www. ecdc.europa.eu/sites/default/files/documents/RRAsixth-update-Outbreak-of-novel-coronavirus-disease2019-COVID-19.pdf.

9. Spadaro R. European Opinion Research Group (EORG) Eurobarometer 58.0. European Union citizens and sources of information about health 2003. Available at: https://ec.europa.eu/commfrontoffice/publicopinion/ archives/ebs/ebs_179_en.pdf. Accessed June 06, 2020.

10. Skinner H, Biscope S, Poland B. Quality of internet access: barrier behind internet use statistics. Soc Sci Med. 2003 Sep;57(5):875-80. doi: 10.1016/s0277-9536(02)00455-0.

11. Skinner H, Biscope S, Poland B, Goldberg E. How adolescents use technology for health information: implications for health professionals from focus group studies. J Med Internet Res. 2003 Dec 18;5(4):e32. doi: 10.2196/jmir.5.4.e32.

12. Gencer ZT. Analysis of validity and reliability of Norman and Skinner's e-health scale literacy for cultural adaptation. Istanbul University Faculty of Communication Journal. 2017 Jul 20;52:131-45 (in Turkish). doi: 10.17064/ iuifd. 333165 .

13. Demirlek D. The knowledge, attitudes and behaviors on influenza vaccination of nurses. Unpublished specialty thesis in medicine (supervisor: Vural EZT). University of Health Sciences, Family Medicine. Istanbul, 2017 (in Turkish).

14. Tekbas ÖF. Erbas ve erlerin aile planlaması egitimi için egitim materyali gelistirilmesi. Unpublished Specialty 
Thesis in Medicine. GATA, Public Health. Ankara, 1997 (in Turkish).

15. Göçer S, Balc1 E, Öcal NÜ. Üniversite ögrencilerinde e-sagl1k okuryazarlig1nın degerlendirilmesi: Yozgat Bozok Üniversitesi örnegi. Poster presented at: The Association of Public Health Professionals, 3. International - 21. National Public Health Congress; November 26-30, 2019; Antalya, Turkey.

16. Sengü1 H, Çınar F, Çapar H, Bulut A, Çakmak C. E-health literacy levels of Health Sciences Faculty students and attitudes for using internet: a foundation university sample. International Journal of Social and Humanities Sciences Research (JSHSR). 2017 Nov 30;12(4):1277-87 (in Turkish).

17. Aktürk Ü. Determination of health literacy levels and factors affecting the E literacy levels of women 18-49 in a family health area. Journal of Human Rhythm. 2018 Mar 26;4(1):52-8 (in Turkish).

18. Ertas H, Kiraç R, Demir RN. Investigation of the relationship between digital literacy and E-health literacy. In: Akbolat M, ed. 3. International - 13. National Congress on Health and Hospital Administration Proceedings. Sakarya, 2019:554-67 (in Turkish).

19. Techataweewana W, Prasertsinb U. Development of digital literacy indicators for Thai undergraduate students using mixed method research. Kasetsart Journal of Social Sciences. 2018 May-August;39(2):215-21 doi: 10.1016/j. kjss.2017.07.001.

20. Baker L, Wagner TH, Singer S, Bundorf MK. Use of the Internet and e-mail for health care information: results from a national survey. JAMA. 2003 May 14;289(18):2400-6. doi: 10.1001/jama.289.18.2400.

21. Sørensen K, Van den Broucke S, Fullam J, Doyle G, Pelikan J, Slonska Z, Brand H; (HLS-EU) Consortium Health Literacy Project European. Health literacy and public health: a systematic review and integration of definitions and models. BMC Public Health. 2012 Jan 25;12:80. doi: 10.1186/1471-2458-12-80.

22. Eichler K, Wieser S, Brügger U. The costs of limited health literacy: a systematic review. Int J Public Health. 2009;54(5):313-24. doi: 10.1007/s00038-009-0058-2. 